\title{
Herbal Treatment For Myiasis In Cattle - A Field Trial
}

\author{
U.Umadevi ${ }^{1}$, T.Umakanthan* \\ ${ }^{1}$ Assistant Professor, Dept. of Botany Specialized with Plant Biotechnology, The Standard Fireworks \\ Rajarathinam college for women, Sivakasi, Virudhunagar Dt, Tamil Nadu, India- 626123. \\ "Corresponding author-Veterinary Surgeon, Veterinary hospital, Sattur, Virudhunagar Dt, Tamil Nadu, India-
} 626203.

\begin{abstract}
Myiasis is tissues infestation by fly maggots. Fifty six cattle clinically infested with maggots were included in this trial. Four control animals given no treatment. Remaining 52 trial cattle were topically applied mixture of Acalypha indica juice extract and Lime water once daily. Recovery was nil and $96 \%$ in control and trial groups respectively.
\end{abstract}

Keywords: Myiasis, Cattle, A.indica, Lime water

\section{Introduction}

In bovine maggots commonly infests vagina and udder, which significantly impairs the productivity. They also penetrate into pre-existing wounds and extend the lesions considerably deep. The herbal formulation is mainly composed of ingredients having rich maggoticidal property. It is found distinctly effective against myiasis in cattle.

In a fly brooding season, 56 cattle aged from 8 months to 4 years, different in sex and breed, were employed clinically. They were presented for maggot infestations in various parts of the body like vulval lips, udder, neck/ shoulder and ventral thigh. Examination revealed larval to adult maggots with off-odour, exudation and bleeding.

Among 56, 4 maintained as control, 52 animals organized trial group.

The trial group animals were topically treated with the herbal formulation containing mixture of equal volumes, 50ml.of Acalypha indica juice extract and Lime water. Dribbled the mix over maggot wounds once daily. Control animal given no treatment.

Trial animals wound healed in 3 to 5 days. No wound healing noticed in control.

The plant kingdom harbors an inexhaustible source of active ingredients invaluable in the treatment of many intractable challenging and chronic diseases. The herbal formulation containing Acalypha indica and Lime water is prepared and used on following traces from the time immemorial.

Acalypha indica leaf powder is applied to maggot-infested wounds (Prota, 2008). Umberto Quattrocchi, (2012), reported that the whole plant has larvicidal property, and leaves anthelmintic. In veterinary medicine, leaves crushed in salt and applied on maggot infested sores.

London Medical Gazette, 1843, reported that dressing with chloride of lime, with a view of stimulating the dormant vascular action, destroys the live maggots imbedded in wounds. In two days, wound looked healthy and no maggots visible and the mass of matter in the spaces become inseparable.

Lime (calcium hydroxide) is an ingredient applied to wounds. The lime will kill the maggots (International Institute of Rural Reconstruction, 1994). In this field study, probably the lime dried out the maggots and caused them to die of water pressure deficiency and concurrently reducing the inflammation.

McIntosh, 2011, reported traditional wound cleansing solutions may not be sufficient for maggot infestations of pre-existing wounds and supplemental treatments may be necessary to effectively treat cases of wound myiasis. On contrary, this herbal formulation is unique, easy, economical and aids fast recovery.

This is only a preliminary study and more work has to be carried out to explore the complete mechanism of action and wonderful properties of this formulation.

\section{Acknowledgement}

The authors thank cattle owners, field veterinarians, traditional practitioner, laboratory technicians, The Director, Department of Animal Husbandry and Veterinary Services, Tamil Nadu, The Principal, SFR college for women, Sivakasi, Tamil Nadu for their various help.

\section{References}

[1]. Prota, Medicinal Plants, Volume 1, Backhuys publishers, Netherlands. , 2008, 23

[2]. Umberto Quattrocchi F.L.S., CRC World Dictionary of Medicinal and Poisonous Plants, CRC press, FL. 2012,36

[3]. London Medical Gazette, Volume II, London. 1843, 804 
[4]. International Institute of Rural Reconstruction, Ethnoveterinary Medicine in Asia: Ruminants, 1994,79

[5]. McIntosh MD, Merritt RW, Kolar RE, Kimbirauskas RK, Effectiveness of wound cleansing treatments on maggot (Diptera, Calliphoridae) mortality, Forensic Sci Int. 2011, 210(1-3):12-5 